\title{
IMMUNOLOGICAL INDICATORS IN ANIMAL ORGANISMS UNDER THE INFLUENCE OF ALLOGENEIC ADIPOSE TISSUE-DERIVED MESENCHYMAL STEM CELLS
}

L. V. KLADNYTSKAㄹ, Doctor of Veterinary Sciences, Associate Professor http://orcid.org/0000-0002-9360-0587

A. Y. MAZURKEVYCH', Doctor of Veterinary Sciences, Professor http://orcid.org/0000-0002-2409-7703

L. V. GARMANCHUK², Doctor of Biological Sciences, Professor http://orcid.org/0000-0002-1527-2346

M. O. MALIUK ${ }^{1}$, Doctor of Veterinary Sciences, Associate Professor http://orcid.org/0000-0003-3019-6035

S. V. VELYCHKO3, Candidate of Biological Sciences http://orcid.org/0000-0003-1842-5114

T. A. MAZURKEVYCH ${ }^{1}$, Doctor of Veterinary Sciences, Associate Professor http://orcid.org/0000-0002-1294-5939

V. V. KOVPAK ${ }^{1}$, Doctor of Veterinary Sciences, Associate Professor http://orcid.org/0000-0003-2419-1246

V. B. DANILOV', Candidate of Veterinary Sciences, Associate Professor http://orcid.org/0000-0002-2897-5235

Yu. O. KHARKEVYCH ${ }^{1}$, Candidate of Veterinary Sciences, Associate Professor http://orcid.org/0000-0002-7877-8272

R. R. ВОКОтKO ${ }^{1}$, Candidate of Veterinary Sciences, Assistant http://orcid.org/0000-0002-6217-5266

T. L. SAVCHUK ${ }^{1}$, Candidate of Veterinary Sciences, Senior Lecturer http://orcid.org/0000-0002-7351-5684

${ }^{1}$ National University of Life and Environmental Sciences of Ukraine, 15 Heroiv oborony st., Kyiv 03041, Ukraine

${ }^{2}$ Taras Shevchenko National University of Kyiv, 60 Volodymyrska st., Kyiv 01033, Ukraine

${ }^{3}$ Veterinary hospital, Holosiivskyi Avenue 105 B, Kyiv 01041, Ukraine,

E-mail: Kladlarisa@ukr.net

\begin{abstract}
The studies were conducted on 2-3 months old males of C57BL/6 mice, weighing 20-24 g. Our work aimed at studying the functional state of the organs of the immune system in mice after administration of allogeneic mesenchymal stem cells of adipose tissue origin. Obtaining and cultivating mesenchymal stem cells were carried out in a sterile laminar box with compliance of asepsis and antiseptic conditions. The abdominal adipose tissue from
\end{abstract}


C57BL/6 mice was cultured in a $\mathrm{CO}_{2}$ incubator at $37^{\circ} \mathrm{C}$ and $5 \% \mathrm{CO}_{2}$ in DMEM with 10-15\% of fetal bovine serum, $1 \%$ of antibiotic/antimycotic solution (Sigma-Aldrich, USA). The following groups of animals were formed: 1 group - intact (control); 2 group - animals, to whom $0.5 \mathrm{~cm}^{3}$ of $0.9 \% \mathrm{NaCl}$ solution (placebo) were injected into the caudal vein; 3 group animals, to whom $10^{4}$ of allogeneic mesenchymal stem cells from adipose tissue in $0.5 \mathrm{~cm}^{3}$ of phosphate buffer solution were injected into the caudal vein. The weight index, the content of lymphoid cells in the thymus and spleen in C57BL/6 mice were examined on days 7, 18, and 25 after the administration of mesenchymal stem cells. To assess the lymphocyte content in lymphoid organs, they were weighed (whole thymus, $50 \mathrm{mg}$ of spleen), triturated, and filtered through the nylon cloth. After that, the tissue homogenate was applied to Ficoll-Urografin density gradient $(d=1.077)$ in a ratio of 3:2. The test tubes were centrifuged at $1500 \mathrm{rpm}$ for 30-40 minutes. After centrifugation, plasma and layer of lymphocytes were above the density gradient; lymphocytes were collected by a Pasteur pipette and washed twice with an arbitrary amount of Hank's solution by centrifugation at 1500 rpm for 10 minutes. After washing, $1 \mathrm{~cm}^{3}$ of Hank's solution was added to lymphocytes and they were counted in the Goryaev chamber. Calculation of the cellularity of lymphoid organs was performed in $1 \mathrm{mg}$ of tissue.

The transplantation of allogeneic adipose-derived mesenchymal stem cells affects the central and peripheral organs of the immune system. Administration of allogeneic adiposederived mesenchymal stem cells causes a significant increase in the content of lymphoid cells in the thymus on days 7, 18, and 25 by 71\%, 57, and 53\% ( $P<0.05)$, respectively, compared to the control. At the 7 and 18 days of the immune response, lymphoid cell content in the spleen significantly increases by 33\% $(P<0.01)$ and $19 \%(P<0.05)$, respectively, compared to the control under the administration of allogeneic adipose-derived mesenchymal stem cells. On day 25, values of lymphoid cell content and spleen index return to normal. The thymus and spleen weight indices directly correlate with their lymphoid cell content.

Keywords: mice, weight index, lymphoid cells, thymus, spleen, allogeneic mesenchymal stem cells, adipose tissue

\section{Introduction}

Important biological features of mesenchymal stem cells (MSCs), in particular, the ability to migrate to the inflammation site, low immunogenicity, immunomodulatory activity, and the ability to stimulate hemopoiesis, make them potentially active regulators of reparative processes (Kladnytska et al., 2014).

At the present stage of the development of biological sciences, different approaches are developed for the use of MSCs in the treatment of various diseases, and several preclinical and clinical trials have already been conducted, the results of which have shown the effectiveness of their application (Haghighat et al., 2011; Reich et al., 2012; Arnhold \& Wenisch, 2015; Jakobsen et al., 2017).

An alternative source of MSCs is adipose tissue, which contains stem cells in a higher percentage than bone marrow. Obtaining adipose tissue is a less traumatic procedure for the donor than the obtaining of bone marrow both during the process of primary material obtaining and postoperative period (Marx et al., 2014; Kladnytska et al., 2017).

Regardless of MSCs origin, they have pronounced immunosuppressive activity: they block in vitro differentiation of naive CD4+ T cells in Th17 and 
suppress the synthesis of many cytokines such as IL-17, IL-22, interferon-gamma, and TNF $\alpha$ (Bartholomew et al., 2002; Gryschenko \& Tomchuk, 2013).

Despite the large number of publications confirming the immunosuppressive properties of MSCs, some works deny such effects on immune responses (Di Nicola et al., 2002; Aggarwal \& Pittenger, 2005; Djouad et al., 2005).

Thus, it was found that transplantation of MSCs stimulates antibody production and increases the cellularity of the bone marrow in recipients. With increasing the number of administered cells, a significant increase in the thymus cellularity and decrease in spleen cellularity were recorded. The authors suggest that a significant dose of MSCs creates a suppressive microenvironment for lymphoid cells that is accompanied by the inhibition of the immune response (Le Blanc et al., 2003; Batten et al., 2006; Lu et al., 2009).

Opposite, a small number of transplanted cells due to homing is collected in the bone marrow niches, contributing to hematopoiesis, where the myeloid sprout can act as an impressive factor in natural immunity (Nikolskaya et al., 2012).

So, it is not well known about the effect of MSCs on the response of the immune organs, in particular, on the functional state of the thymus and spleen. Taking into account such controversial data on the influence of MSCs on the organs of the immune system, these issues require further research.

The purpose of our work was to study the functional state of the organs of the immune system in C57BL/6 mice after the administration of allogeneic adipose MSCs.

\section{Materials and methods of researches}

The studies were carried out on 2-3 months old males of C57BL/6 mice, weighing 20-24 g. All experiments were conduct- ed in accordance with the Good Laboratory Practices regulations in research studies using animals, the Law of Ukraine On the Protection of Animals from Brutal Treatment, and the European Convention for the Protection of Vertebrate Animals used for Experimental and other Scientific Purposes.

MSCs obtaining from adipose tissue. Obtaining and cultivating adipose MSCs (aMSCs) were carried out in a sterile laminar box with compliance of asepsis and antiseptic conditions. The mice were euthanized, samples of abdominal adipose tissue were washed three times with sterile phosphate buffer solution with the addition of $1 \%$ antibiotic/antimycotic solution (Sigma-Aldrich, USA). Then samples of adipose tissue were chopped into pieces of $1-3 \mathrm{~mm}^{3}$ and placed to culture dishes filled with DMEM, $10-15 \%$ of fetal bovine serum, $1 \%$ antibiotic/antimycotic solution (Sigma-Aldrich, USA) and cultured in a $\mathrm{CO}_{2}$ incubator at $37^{\circ} \mathrm{C}$ and $5 \%$ $\mathrm{CO}_{2}$. The culture medium was partially or completely changed by fresh medium every 3 days during cultivation. After formation of cell monolayer by $80-90 \%$, cells were removed with trypsin/ethylenediaminetetraacetic acid solution (EDTA), washed with phosphate buffer, and placed into Petri dishes for further cultivation. Cell passaging provided a reduction in the heterogeneity of cell culture and the development of biological material for transplantation (Kladnytska et al., 2016). MSCs at passage 4 were used for transplantation.

MSC administration to mice. The following groups of animals were formed: 1 - intact (control); 2 - animals, to whom $0.5 \mathrm{~mL}$ of $0.9 \% \mathrm{NaCl}$ solution (placebo) were injected into the caudal vein; 3 - animals, to whom $10^{4}$ of allogeneic aMSCs in $0.5 \mathrm{~mL}$ of phosphate buffer solution were injected into the caudal vein.

Estimation of the thymic and splenic weight indices in mice after aMSC admin- 
istration. Indicators of the weight of peripheral lymphoid organs relative to the body weight (weight index) of animals were evaluated on days 7,18 , and 25 after aMSC administration. The mice were pre-weighed for weight control. At each experimental period, 3 animals were euthanized in each group and the weight index of lymphoid organs and their cellularity were studied. Euthanasia of animals was carried out using carbon dioxide; lymphoid organs (thymus and spleen) were removed and their mass was determined. Indices of lymphoid organs in relation to the weight of the animal were calculated according to the formula:

Evaluation of the thymic and splenic cellularity after aMSC administration. To assess the content of lymphocytes in lymphoid organs, the latter were weighed. The whole thymus and $50 \mathrm{mg}$ of spleen were triturated and filtered through the nylon cloth. After that, the cell homogenate was applied to Ficoll-Urografin density gradient $(d=1.077)$ in a ratio of $3: 2$. The test tubes were centrifuged at a rate of 1500 rpm for 30-40 minutes. After centrifugation, the layer of lymphocytes, which was located above the density gradient, was collected by a Pasteur pipette and washed twice with an arbitrary amount of Hank's solution by centrifugation at a rate of 1500 rpm for 10 minutes. After washing, $1 \mathrm{ml}$ of Hank's solution was added to lymphocytes. Lymphocytes were counted in the Goryaev chamber. Calculation of the lymphoid organ cells was performed on $1 \mathrm{mg}$ of tissue.

\section{Results of the research and their discussion}

The functional state of the organs of immunogenesis largely depends on the ratio of processes of immune cell proliferation and apoptosis, that almost are not studied after MSC administration.

After allogeneic aMSC administration, the content of lymphoid cells in the thymus on days 7,18 , and 25 significantly increased by $71 \%, 57$, and $53 \%$, respectively, compared with control animals (Table 1).

Compared with a placebo group, the content of lymphoid cells in the thymus was significantly increased by $42 \%, 69$, and $86 \%$, respectively. The increase in thymic cellularity is associated with the activation of residential thymocyte proliferation due to antigenic stimulation by MSCs that is consistent with the studies of Huang et al. (2009). The thymus contains T lymphoblasts, immature and mature lymphocytes, supporting and secretory cells of the thymus stromal component (Fig. 2).

A positive correlation between the content of lymphoid cells and thymic weight index was found 7 days after aMSCs administration. Thymic weight index directly correlates with the content of lymphoid cells and its value was

\section{The content of lymphoid cells and the weight index of the thymus in C57BL/6 mice after allogeneic aMSC administration $(M \pm m, n=9)$}

\begin{tabular}{|c|c|c|c|c|}
\hline \multirow[b]{2}{*}{ Day } & \multicolumn{3}{|c|}{ The content of lymphoid cells, $\times 10^{6} / \mathrm{mg}$} & \multirow{2}{*}{$\begin{array}{l}\text { thymic weight index } \\
\text { after administration } \\
\text { of aMSC, } \%\end{array}$} \\
\hline & $\operatorname{intact}(n=6)$ & $\begin{array}{c}\text { administration of } 0.89 \% \\
\mathrm{NaCl} \text {, placebo }(\mathrm{n}=9)\end{array}$ & $\begin{array}{c}\text { administration } \\
\text { of aMSCs }(n=9)\end{array}$ & \\
\hline 7 & $1.4 \pm 0.1$ & $1.9 \pm 0.2$ & $2.7 \pm 0.1 * \mathrm{v}$ & $0.19 \pm 0.03 * \mathrm{v}$ \\
\hline 18 & $1.4 \pm 0.1$ & $1.3 \pm 0.1$ & $2.2 \pm 0.1 * \mathrm{v}$ & $0.16 \pm 0.01 * \mathrm{v}$ \\
\hline 25 & $1.7 \pm 0.1$ & $1.4 \pm 0.1$ & $2.6 \pm 0.3 * \mathrm{vv}$ & $0.17 \pm 0.01 * \mathrm{v}$ \\
\hline
\end{tabular}

Note: $* \mathrm{P}<0.05, * * \mathrm{P}<0.01$ compared to intact animals; $\mathrm{v} \mathrm{P}<0.05, \mathrm{vv} \mathrm{P}<0.01$ compared to placebo group. 


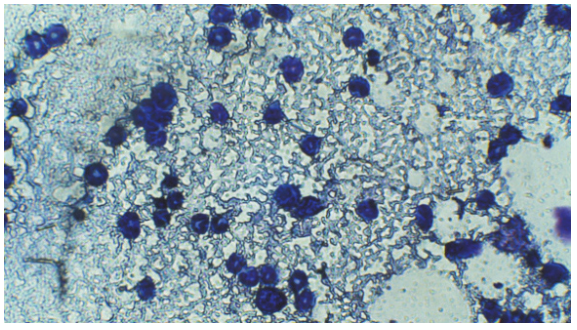

A

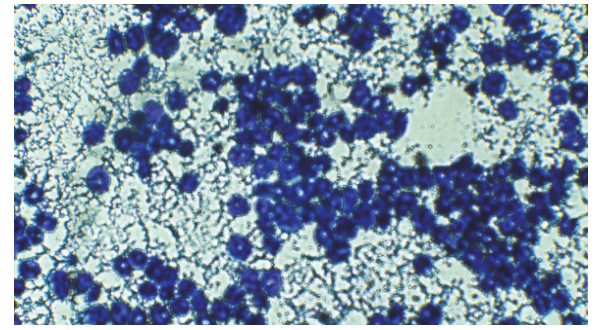

$\mathrm{B}$

Fig. 2. Thymic cellularity on day 7 of the experiment:

A - intact group, B - after aMSC administration (smear-imprint, x 400)

$\mathrm{r}=0.57(\mathrm{P}<0.01)$ on day 7 and $\mathrm{r}=0.50$ $\mathrm{P}<0.05$ on day 18 of the experiment.

Under the influence of MSCs from adipose tissue, the indicator of splenic weight index was significantly increased until day 18 of the experiment (Table 2). On day 25, the splenic weight index did not significantly differ from that in the experimental group and placebo animals, but only observed a tendency to increase it.

The spleen, as the peripheral organ of the immune system, is also involved in the process of forming an immune response to the antigen. After MSC administration, the content of lymphoid cells in the spleen significantly exceeded the parameters of spleen cellularity in intact animals (Table 2). Smear-imprint contains erythroid cells, neutrophil granulocytes, monocytes. and lymphoid cells.

The number of lymphoid cells significantly increased by 33 and $24 \%$ compared to intact animals and the placebo group on day 7 of the experiment. On day 18 of the experiment, the spleen cellularity under the influence of MSCs from adipose tissue was significantly higher by 19 and $14 \%$, respectively. On day 25 of the experiment, the lymphoid cell count was higher by 7 and $15 \%$ within the tendency.

The splenic weight index directly correlates with the content of lymphoid cells in them $r=0.91(\mathrm{P}<0.001), r=0.94$ $(\mathrm{P}<0.001), \mathrm{r}=0.92(\mathrm{P}<0.001)$ on day 7 , 18 and 25 of the experiment, respectively. Such changes indicate a direct reaction of the spleen to the administration of allogeneic MSC from adipose tissue.

Thus, the administration of allogeneic MSCs isolated from adipose tissue from $\mathrm{C} 57 \mathrm{Bl} / 6$ mice causes systemic effects on the thymus and spleen. As a result of antigenic stimulation by allogeneic stem cells, there is an increase in mitotic activity of thy-

\section{The content of lymphoid cells and splenic weight index in C57BL/6 mice after allogeneic aMSC administration $(\mathrm{M} \pm \mathrm{m})$}

\begin{tabular}{|c|c|c|c|c|}
\hline \multirow[b]{2}{*}{ Day } & \multicolumn{3}{|c|}{ The content of lymphoid cells, x $10^{6} / \mathrm{mg}$} & \multirow{2}{*}{$\begin{array}{l}\text { Splenic weight index } \\
\text { after administration } \\
\text { of aMSC, } \%\end{array}$} \\
\hline & $\operatorname{intact}(n=6)$ & $\begin{array}{c}\text { administration of } 0.89 \% \\
\mathrm{NaCl} \text {, placebo }(\mathrm{n}=9)\end{array}$ & $\begin{array}{l}\text { administration of } \\
\text { aMSCs }(n=9)\end{array}$ & \\
\hline 7 & $2.7 \pm 0.1$ & $2.9 \pm 0.1$ & $3.6 \pm 1.1 * * \mathrm{vv}$ & $0.79 \pm 0.04 * \mathrm{v}$ \\
\hline 18 & $2.7 \pm 0.1$ & $2.8 \pm 0.4$ & $3.2 \pm 0.1 * \mathrm{v}$ & $0.79 \pm 0.04 * \mathrm{v}$ \\
\hline 25 & $2.7 \pm 0.1$ & $2.5 \pm 0.1$ & $2.9 \pm 0.1$ & $0.46 \pm 0.03$ \\
\hline
\end{tabular}

Note: $* \mathrm{P}<0.05, * * \mathrm{P}<0.01$ compared to intact animals; $\mathrm{v} \mathrm{P}<0.5, \mathrm{vv} \mathrm{P}<0.01$ compared to placebo group. 


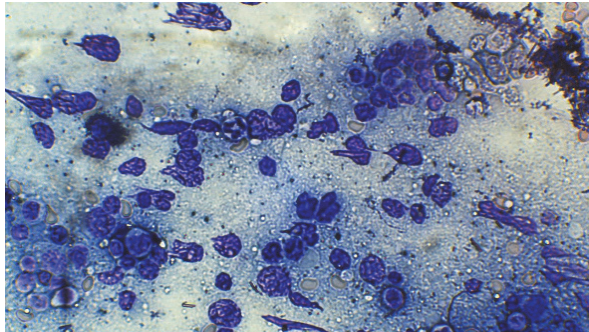

A

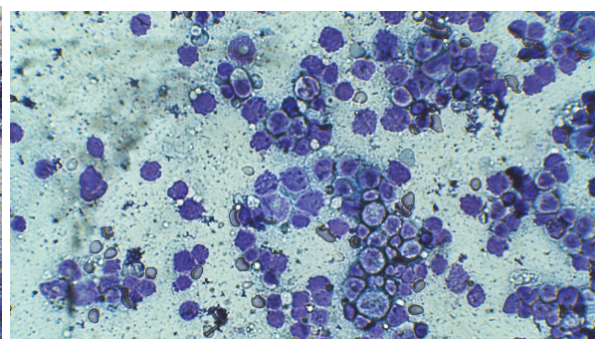

B

Fig. 2. The spleen cellularity on day 7 of the experiment:

A - intact group, B - after aMSC administration, (smear-imprint, x 400)

mocytes and splenocytes. Despite numerous publications that reveal the immunological properties of cells and confirm the presence of immunosuppressive effects, the results of individual scientific studies show that MSCs under certain conditions can be eliminated by cells of the immune system in recipient animals since they have signs of foreignness (Huang et al., 2009).

The increase in the content of lymphoid cells in the thymus and spleen after aMSC administration in our mind may be due to the heterogeneity of introduced cell cultures, an insufficient number of introduced cells for the implementation of immunosuppressive effect, as well as low concentration of immunosuppressive factors synthesized by MSCs.

\section{Conclusion}

1. The administration of allogeneic adipose-derived mesenchymal stem cells affects the central and peripheral organs of the immune system.

2. Administration of allogeneic adipose-derived mesenchymal stem cells causes a significant increase in the content of lymphoid cells in the thymus by 71,57 , and $53 \%$ $(\mathrm{P}<0.05)$ on days 7,18 , and 25 , respectively, compared to the control.

3. Thymic weight index directly correlates with the content of lymphoid cells and its value was $r=0.57(P<0.01)$ on day 7 and $\mathrm{r}=0.50(\mathrm{P}<0.05)$ on day 18 .

4. Lymphoid cell count in the spleen significantly increase on days 7 and 18 of the immune response by $33(\mathrm{P}<0.01)$ and $19 \%(\mathrm{P}<0.05)$, respectively, compared to the control under the administration of allogeneic adipose-derived mesenchymal stem cells.

5. On the 25th day, the content of lymphoid cells in the spleen and spleen index values return to normal.

6. Splenic weight index directly correlates with the content of lymphoid cells in it $-\mathrm{r}=0.91-0.94(\mathrm{P}<0.001)$.

\section{References}

Aggarwal, S., \& Pittenger, M. F. (2005). Human mesenchymal stem cells modulate allogeneic immune cell responses. Blood, 105(4), 1815-1822.

Arnhold, S., \& Wenisch, S. (2015). Adipose tissue derived mesenchymal stem cells for musculoskeletal repair in veterinary medicine. American journal of stem cells, 4(1), 1.

Bartholomew, A., Sturgeon, C., Siatskas, M., Ferrer, K., Mclntosh, K., Patil, S., ... \& Hoffman, R. (2002). Mesenchymal stem cells suppress lymphocyte proliferation in vitro and prolong skin graft survival in vivo. Experimental hematology, 30(1), 42-48.

Batten, P., Sarathchandra, P., Antoniw, J. W., Tay, S. S., Lowdell, M. W., Taylor, P. M., \& Yacoub, M. H. (2006). Human mesenchymal stem cells induce 
T cell anergy and downregulate $T$ cell allo-responses via the TH2 pathway: relevance to tissue engineering human heart valves. Tissue engineering, 12(8), 2263-2273.

DiNicola,M.,Carlo-Stella,C.,Magni,M.,Milanesi,M., Longoni, P. D., Matteucci, P., ... \& Gianni, A. M. (2002). Human bone marrow stromal cells suppress T-lymphocyte proliferation induced by cellular or nonspecific mitogenic stimuli. Blood, The Journal of the American Society of Hematology, 99(10), 3838-3843.

Djouad, F., Fritz, V., Apparailly, F., Louis-Plence, P., Bony, C., Sany, J., ... \& Noël, D. (2005). Reversal of the immunosuppressive properties of mesenchymal stem cells by tumor necrosis factor $\alpha$ in collagen-induced arthritis. Arthritis \& Rheumatism, 52(5), 1595-1603.

Haghighat, A., Akhavan, A., Hashemi-Beni, B., Deihimi, P., Yadegari, A., \& Heidari, F. (2011). Adipose derived stem cells for treatment of mandibular bone defects: An autologous study in dogs. Dental research journal, 8(Suppl1), S51.

Huang, Y., Johnston, P., Zhang, B., Zakari, A., Chowdhry, T., Smith, R. R., ... \& Womer, K. L. (2009). Kidney-derived stromal cells modulate dendritic and T cell responses. Journal of the American Society of Nephrology, 20(4), 831-841.

Gryschenko, V. A., \& Tomchuk, V. A. (2013). Imunomodulyuyuchi vlastivosti liposom na osnovi fosfolipidiv moloka pry imunodefitsitnomu stani organizmu tvaryn [Immunomodulatory properties of liposomes based on milk phospholipids in immunodeficiency of animals]. Naukoviy visnik NUBIP Ukrainy, 188(4), 107-115.

Jakobsen, K. K., Grønhøj, C., Jensen, D. H., Fischer-Nielsen, A., Hjuler, T., \& von Buchwald, C. (2017). Mesenchymal stem cell therapy for laryngotracheal stenosis: a systematic review of preclinical studies. PloS one, 12(9), e0185283. doi: 10.1371/journal.pone.0185283

Kladnytska, L.V., Nikulina, V.V., Garmanchuk, L.V., Mazurkevych, A. Y., Kovpak, V. V., Nikolaienko, T. V. ... \& Dasyukevich, O. I. (2014). Influence allogeneic mesenchymal stem cells on the tumour growth parameters and metastatic potential in the transplantable carcinoma lung Lewis. Journal of Animal and Veterinary Sciences, 1(1), 1-5.

Kladnytska, L. V., Mazurkevich, A. Y., Bezdenezhnih, N. O., Chehun, V. F., Velychko, S. V., Maliuk, M. O. ... \& Harkevych, Yu. O. (2017). Ekspresiya tsitoplazmatichnih bilkiv stovburovimi klitinami z zhirovoyi tkanini sobaki na riznih pasazhah kultivuvannya in vitro [Expression of cytoplasmic proteins by dog adipose tissue stem cells at different passages of in vitro culture]. Naukovo-tehnichniy byuleten naukovo-doslidnogo kontrolnogo Institutu veterinarnih preparatlv $\mathrm{i}$ kormovih dobavok institutu biologiyi tvarin, 18(1), 48-55.

Kladnytska, L. V., Mazurkevich, A. Y., \& Velichko, S. V. (2016). Sposib otrimannya mezenhimalnih stovburovih klitin iz zhirovoyi tkanyny sobaki. Patent 109148 Ukraine. Kyiv: State Patent Office of Ukraine.

Le Blanc, K., Tammik, L., Sundberg, B., Haynesworth, S. E., \& Ringden, O. (2003). Mesenchymal stem cells inhibit and stimulate mixed lymphocyte cultures and mitogenic responses independently of the major histocompatibility complex. Scandinavian journal of immunology, 57(1), 11-20.

Lu, X., Liu, T., Gu, L., Huang, C., Zhu, H., Meng, W., ... \& Liu, Y. (2009). Immunomodulatory effects of mesenchymal stem cells involved in favoring type $2 \mathrm{~T}$ cell subsets. Transplant immunology, 22(1-2), 55-61.

Marx, C., Silveira, M. D., Selbach, I., da Silva, A. S., Braga, L. M. G. D. M., Camassola, M., \& Nardi, N. B. (2014). Acupoint injection of autologous stromal vascular fraction and allogeneic adipose-derived stem cells to treat hip dysplasia in dogs. Stem Cells International, 2014.

Nikolskaya, V. V., Savinova, V. O., Semenova, Ya. M. O., Taranuha, L. I., \& Nikolskiy, I. S (2012). Vliyanie vnutrivennogo vvedeniya multipotentnyih stromalnyih kletok timusa na proliferativnuyu fazu immunnogo otveta [Influence of intravenous administration of multipotent thymus stromal cells on the proliferative phase of the immune response]. Zhurnal NAMN Ukrainy, 18, 105-106. 
Reich, C. M., Raabe, O., Wenisch, S., Bridger, P. S., Kramer, M., \& Arnhold, S. (2012). Isolation, culture and chondrogenic differentiation of canine adipose tissue-and bone marrow-derived mesenchymal stem cells-a comparative study. Veterinary research communications, 36(2), 139-148.

\section{Л. В. Кладницька, А. Й. Мазуркевич, Л. В. Гарманчук, М. О. Малюк, С. В. Величко, Т. А. Мазуркевич, В. В. Ковпак, В. Б. Данілов, Ю. О. Харкевич, Р. Р. БоКОТЬКО, Т. Л. СавЧУК (2021). ІМУНОЛОГІЧНІ ПОКАЗНИКИ ОРГАНІЗМУ ТВАРИН ЗА ВПЛИВУ АЛОГЕННИХ МЕЗЕНХІМНИХ СТОВБУРОВИХ КЛІТИН КУЛЬТУРИ ЖИРОВОї ТКАНИНИ. Ukrainian Journal of Veterinary Sciences, 12(2): 59-76,} https://doi.org/10.31548/ujvs2021.02.006

Анотація. Дослідження проводили на самиях мишей C57BL/6 вагою 20-24 г, віком 2-3 місяці. Метою нашої роботи було вивчення функціонального стану органів імунної системи у мишей після введення алогенних мезенхімальних стовбурових клітин із жирової тканини. Маніпуляції з отримання первинного матеріалу та культивування мезенхімальних стовбурових клітин здійснювали в стерильному боксі з дотриманням усіх правил асептики й антисептики. Абдомінальну жирову тканину мишей C57BL/6 культивували у $\mathrm{CO}_{2}$ інкубаторі за температури $37^{\circ} \mathrm{Ci}$ 5\% $\mathrm{CO}_{2}$ в середовищі DMEM, з додаванням 10-15\% фетальної сироватки бичків, $1 \%$ антибіотика-антимікотика (Sigma-Aldrich, USA). Для проведення досліджень було сформовано такі групи тварин: 1 група-інтактні (контрольна група); 2 група-тварини, яким у хвостову вену вводили 0,5 $\mathrm{cm}^{3}$ 0,9\% розчину $\mathrm{NaCl}$ (плацебо); 3 група - тварини, яким у хвостову вену вводили $10^{4}$ алогенних мезенхімальних стовбурових клітин із жирової тканини в 0,5 $\mathrm{cm}^{3}$ фососратно-буферного розчину. Досліджували ваговий індекс, вміст лімфоїдних клітин тимусу та селезінки мишей C57BL/6 за введення мезенхімальних стовбурових клітин із жирової тканини. Для оцінювання вмісту лімфоцитів у лімфоїдних органах, останні зважували (тимус повністю), а селезінку - по 50 мг, потім розтирали та фільтрували через капронову тканину. Після цього гомогенат тканини наносили на градієнт фікол-верографріну (щільність 1,077) у співвідношенні 3:2. Пробірки з вмістом центрифругували зі швидкістю 1500 об/хв., упродовж 30-40 хв. Після центрифугування над шаром градієнта залишається плазма й лімфоцити (не менше 90\%), які збирали пастерівською піпеткою і двічі відмивали довільною кількістю розчину Хенкса за допомогою чентрифугування за швидкості обертання 1500-1800 об/хв. упродовж 10 хв. Після відмивання до лімфоцитів додавали $1 \mathrm{~cm}^{3}$ розчину Хенкса й підраховували їхню кількість у камері Горяєва. Розрахунок клітинності лімфоїдних органів проводили на 1 мг тканини.

Трансплантація алогенних мезенхімальних стовбурових клітин із жирової тканини чинить вплив на центральні й периферичні органи імунної системи. За впливу алогенних мезенхімальних стовбурових клітин із жирової тканини відбувається достовірне підвищення вмісту лімфоїдних клітин тимусуна ранніхіпізніхетапахімунноївідповідіна 7, 18 та 25 добувідповідно на 71\%, 57і53\% $(P<0,05)$ порівнюючи з контролем. Кількість лімфоїдних клітин у селезінці достовірно зростала на 7 та 18 добу імунної відповіді відповідно на 33\% та 19\%, ( $P<0,01, P<0,05)$ порівнюючи з контролем за введення алогенних мезенхімальних стовбурових клітин, одержаних із жирової тканини. Ha 25 добу показники вмісту лімфоїдних клітин та індексу селезінки повертаються до норми. Iндекси ваги тимуса й селезінки прямо корелюють з вмістом лімфоїдних клітин у цих органах.

Ключові слова: миші, ваговий індекс, лімфоїдні клітини, тимус, селезінка, алогенні мезенхімальні стовбурові клітини, жирова тканина 